\title{
Influence of Subjective Norms on the Use of Information and Communication Technologies for Agricultural Risk Management: Empirical Evidence from Malaysia
}

\author{
Muhammad Ali ${ }^{*}$, Norsida Man ${ }^{2}$ and Farrah Melissa Muharam² \\ ${ }^{1}$ Department of Agricultural Extension, PMAS-Arid Agriculture University Rawalpindi, Pakistan; ${ }^{2}$ Department of Agriculture \\ Technology, Universiti Putra Malaysia, Malaysia.
}

\begin{abstract}
Social influence plays a significant role in the adoption of new technologies exclusively in the context of climate change. Although various studies have been undertaken to manage agricultural risk from the field perspective. However, less attention has been paid to examine the influence of subjective norms on ICT usage among farmers for the management of agricultural risk in Malaysia. Therefore, the present study was designed to meet the objective. The research data were collected through a field survey in which 360 farmers were interviewed through the multistage cluster sampling technique. The subjective norms were measured through 5 points Likert scale (ranging from 1 as strongly disagree to 5 as strongly agree) based statements. The result exhibited that farmers had realized the significance of ICTs which helped them in staying connected with fellow farmers and extension service providers. Furthermore, majority of the farmers had a high level of subjective norms influence to use ICTs for agricultural risk management. However, it seems that still a lot to be done in order to socially influence farmers particularly resource poor farmers to use ICTs for agricultural risk management for ultimately coping with the impacts of climate changes. Last but not least, agricultural extension service providers are urgently needed to organize farmers to address climate changes collectively.

Received | May 13, 2019; Accepted | July 21, 2019; Published | August 15, 2019

*Correspondence | Muhammad Ali, Department of Agricultural Extension, PMAS-Arid Agriculture University Rawalpindi, Pakistan; Email: aliupm115@gmail.com

Citation | Ali, M., N. Man and F.M. Muharam. 2019. Influence of subjective norms on the use of information and communication technologies for agricultural risk management: empirical evidence from Malaysia. Pakistan Journal of Agricultural Research, 32(3): 555-561.

DOI | http://dx.doi.org/10.17582/journal.pjar/2019/32.3.555.561

Keywords | Subjective norms, ICT, Agricultural risk management, Agricultural Extension, Malaysia
\end{abstract}

\section{Introduction}

$\mathrm{F}$ armers are socially dependent to transfer and receive valuable agricultural information. A farmer sometimes becomes a recipient or even become a source of technology transfer to other farmers. The social ties between farmers influence them to not only adopt technological innovations but also help in collective decisions. According to El Bilali and Allahyari (2018) farmers need to communicate, make agricultural transactions, exchange information and transfer knowledge so various ICTs assist farmers to do quickly and easily. However, due to diversification in technologies and functions, the selection and appropriate use could also be linked with social networks as these formal and informal networks aid farmers to use in an appropriate way. That is why Lehmann et al. (2012) highlighted that social media networks play a prime role in the development sector by uniting network technology with human networks. 
Information and Communication Technologies (ICTs) is an umbrella term which contains computer software and hardware, telecommunication technologies, broadcasting through digital means along with digital sources of information which may be online or offline (Selwyn, 2002), So, ICTs are package of services, tools, applications, soft wares and hardware which may be used to communicate in a quicker way. ICTs have potential to improve lives of users and are being used in the agriculture and other sectors such as public, private, transport, education are names a few (Haftu, 2019). Farmers also use various ICTs especially mobile phone to remain connected in the world as these digital blessings aid farmers to receive weather forecasts, stay update about market fluctuations, maintain farm data, consult extension service providers, learn and/or share valuable information about pest/disease attack with fellow farmers and make online financial transactions. Importantly, ICTs assist farmers to bridge the gap between farmers and extension agents.

Climate changes also influence farmers to cope with the uncertainties accordingly. In this regard, farmers use various adaptation techniques and some of the important ones are agricultural diversification, advance savings, crop insurance, crop sharing and change of sowing time and variety to mitigate the adverse impacts of climate changes (Alemayehu and Bewket, 2017; Ali et al., 2018b; Mubiru et al., 2018; Aniah et al., 2019). Likewise, ICTs help farmers to handle agricultural risk (s) timely and quickly. In this regard, people in social circle such as fellow farmers and agricultural advisors make every effort to minimize the negative impacts of climate changes.

Climate change impacts are being witnessed by farmers and their fellow farmers (Ali et al., 2019). According to Jellason et al. (2019) developing world has seen the low agriculture yield and food insecurity issue on account of climate changes. So, uncertain events could lead to more hurdles in the agriculture and food sector in the years to come. It is also a bitter fact that social networks of farmers are either not funded or less funded which affect their adoption and adaptation of new technologies for tackling with the climate changes. Di Falco and Sharma-Khushal (2019) hold an opinion that cost-effective measures with timely information provision could positively affect behavioural change among the farmers. Thus, the social networks could help in ensuring motivation of farmers to maximize their production and not to abandon this vocation due to extreme climate events.

A subjective norm is associated with perceived social influence to indulge or not to indulge in a given behaviour (Ajzen, 1991). So, people who are close such as relatives, peer farmers and extension service providers could influence farmers to indulge or not to indulge in agricultural risk management through ICTs. According to Wang (2018), solo actions are usually limited so social and behavioural change is often performed through collective decisions. In this regard, Naylor and Courtney (2014) highlighted that decisions by an individual are hardly taken even with full knowledge of costs, benefits or risks. Some of the researchers have also pointed out the significance of social networks in agriculture and risk management such as Bernier and Meinzen-Dick (2014), Isaac (2012), Matuschke (2008) and Adger et al. (2005). However, Cadger et al. (2016) specified that more information is needed to examine the structure, influences of these networks on the sharing of knowledge mechanism and results of knowledge transfer to the other farmers.

Although a good number of studies have been conducted empirically to examine impacts of social norms in various contexts and dimensions however less attention has been paid in the domain of ICTs usage for agricultural risk management. Therefore, the present study was designed with the objective to assess the influence of subjective norms to use ICTs for agricultural risk management in the context of Malaysia. The results would be helpful for farmers, extension agents, researchers and policy makers to understand the importance of social influence (subjective norms) to mitigate the impacts of climate change through apt agricultural risk management strategies.

\section{Materials and Methods}

In order to conduct this study, the farmers were interviewed with the pre-designed questionnaire. The questionnaire was pre-tested on 50 farmers who were not considered in the final statistical analysis. There were 360 farmers selected through multistage cluster sampling technique. The research was conducted in three zones of Malaysia namely East zone, South zone and North zone. The validity and reliability of the questionnaire was ensured. The result of the 
reliability analysis showed that alpha value was above 0.60 for all the statements. Likewise, the validity of the research instrument was confirmed through expert consultation. The subjective norms were measured through 5 point Likert scale items in which 1 reflected as strongly disagree and 5 as strongly agree. Furthermore, the level of subjective norms was measured on three levels namely low (1.00 to 2.33), moderate (2.34 to 3.66) and high (3.67 to 5.00) through data transformation. Plus, the class interval formula was used to see low, moderate and high level. The services of local enumerators were hired to gather the data as the questionnaire was translated from English to Bahasa Melayu language. The team of data collectors was pre-trained. In the training sessions, the enumerators were asked to obtain positive consent of the respondents in advance so that no hurdle should delay the data collection process. Thus, the respondents were briefed about the aims and objectives of the research. The collected data were analysed through statistical software (SPSS, version 21).

\section{Results and Discussion}

It is a psychology of an individual to either socially influence others or get influenced by others. The social pressure could arise from fellow farmers, public and private extension services providers, middlemen, and/or opinion leaders. Thus, the subjective norms prevailing in the research area were measured through likert scale items. The digital interventions such as ICTs (old and/or new) play a significant role in the development of the agricultural sector and social interactions could have played a pivotal role without proper capacity and competency building programmes around the globe. However, the results and intensity of peer pressure could vary from area to area and the situations. Thus, farmers in Malaysia were also socially linked to use ICTs for agricultural risk management.

According to the results in Table 1, more than half of the research population (53.9\%) strongly agreed that fellow farmers thought that they should take benefit of ICTs for staying connected with other farmers and extension agents. However, only $13.3 \%$ of the respondents were uncertain in this regard. So, it reflects that the majority of the respondents (by combining $31.1 \%$ and $53.9 \%$ ) held an opinion that their peers should remain in connection for taking benefits from ICT usage for agricultural risk management. Indeed,
ICTs are useful in exchanging valuable agricultural information and answering questions to each other whenever and where ever required. According to Aldosari et al. (2017), digital technologies help farmers to quickly receive information or solution about pest and disease attacks, flood and adverse weather warnings however, farmers could still keep a distance from extension staff on account of the status and educational or other barriers. Importantly, extension agents of public and private sector need to create cordial relations and offer the solution at the door step or through ICTs. That is why Ali et al. (2018a) highlighted that farmers do not get support from extension field staff to use ICTs for agricultural risk management in the context of Malaysia.

Additionally, approximately half of the target population (49.4\%) opined that peer farmers who were close to each other should learn about agricultural risk management techniques. Conversely, only negligible number of farmers $(0.6 \%$ and $1.7 \%)$ were disagreed and strongly disagreed on this point. It showed that an overwhelming majority were agreed and strongly agreed to learn about risk management techniques as climate changes are frequent. As floods and land sliding occur more often than not in Malaysia so, learning attitude could be beneficial for the entire farmers. In this regard, not only natural disasters affect farms and farmers but also followed by insect/pest and disease attacks, water shortage, food insecurity and low production. According to Shikuku (2019), social learning increases the adoption of technologies in the context of agriculture. In this perspective, extension agents could a play prime role in imparting knowledge and new skills among farmers to become resilient. Olorunfemi et al. (2019) and Akhtar et al. (2019) stated that the role of extension workers around the globe is crucial and there is a dire need to empower extension agents as they lack a wide range of knowledge about solutions of climate smart agriculture.

There were $48.6 \%$ and $37.8 \%$ farmers who agreed and strongly agreed that their fellow farmers were interested to help each other whenever they faced any difficulty in the application of risk management strategies. Nevertheless, $11.7 \%$ of the farmers were uncertain in this regard. It shows that farmers had realized to help each other to tackle the problems, as agriculture was the main source of their livelihood. Similarly, fellow farmers influenced the behaviour 
Table 1: Influence of Subjective norms on ICTS use for agricultural risk management.

\section{Statements}

\section{Subjective norms}

Fellow farmers who are important to me think that I should take advantage of ICTs for staying connected with the people like other farmers, extension workers.

Fellow farmers who are close to me think that I should learn about risk management techniques.

My fellow farmers always interested to help me when I have difficulty about management of risk in agriculture.

People (other fellow farmers) who influence my behaviour think that It is good to apply agricultural risk management.

Follow farmers want me to observe their results in agricultural $9(2.5)$ risk management so ICTs help me.

People who are important to me think that I should assess agriculture risks.

People (fellow farmers) who influence my behaviour think that 3(0.8)

I should transfer new risk management techniques (s) to other farmers through ICTs.

People (fellow farmers) who are important to me think that I should try to use new ICTs.

People (fellow farmers) expect that I should contact immediately for solutions of pest/disease attack to avoid any agricultural risk.

My peer farmers want me to practice various risk management 5(1.4) strategies for better production.

People (fellow farmers) who are important to me think that I should also rely on expert recommendations through ICTs for agricultural risk management.

People (other fellow farmers) want me to get the good results of implementing agricultural risk management strategies.

Fellow farmers observed that I am weak to manage agriculture $\quad 15(4.2) \quad 95(26.4) \quad 142(39.4) \quad 71(19.7) \quad 37(10.3) \quad 3.06 \quad 1.019$ risk through new techniques.

Total Average Mean

\section{Scale frequency (percentage)}

Mean S.D.
2

3

4 $\begin{array}{lllllll}6(1.7) & 0(0.0) & 48(13.3) & 112(31.1) & 194(53.9) & 4.36 & 0.835\end{array}$

$\begin{array}{lllllll}2(0.6) & 6(1.7) & 39(10.8) & 178(49.4) & 135(37.5) & 4.22 & 0.745\end{array}$

$\begin{array}{lllllll}2(0.6) & 5(1.4) & 42(11.7) & 175(48.6) & 136(37.8) & 4.22 & 0.745\end{array}$

$\begin{array}{lllllll}4(1.1) & 3(0.8) & 51(14.2) & 170(47.2) & 132(36.7) & 4.18 & 0.783\end{array}$

$\begin{array}{llllll}10(2.8) & 54(15.0) & 145(40.3) & 142(9.2) & 4.11 & 0.933\end{array}$

$32(8.9) \quad 14(3.9) \quad 174(48.3) \quad 134(37.2) 4.11 \quad 0.953$

$\begin{array}{llllll}12(3.3) & 38(10.6) & 200(55.6) & 107(29.7) & 4.10 \quad 0.776\end{array}$ $\begin{array}{lllllll}6(1.7) & 10(2.8) & 29(8.1) & 220(61.1) & 95(26.4) & 4.08 & 0.775\end{array}$

$\begin{array}{lllllll}8(2.2) & 21(5.8) & 107(29.7) & 139(38.6) & 85(23.6) & 3.76 & 0.954\end{array}$

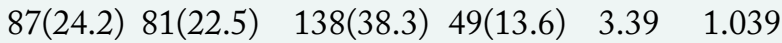

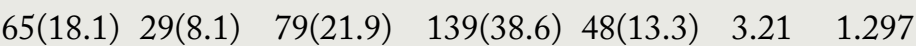

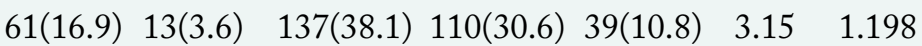

Scale: 1=Strongly Disagree, 2=Disagree, 3=Uncertain, 4=Agree, 5=Strongly Agree; Source: Field survey.

of other farmers $(47.2 \%$ and $36.7 \%)$ to realize that it is good to execute agricultural risk management techniques. On the other side, there were $14.2 \%$ of the farmers who were uncertain on this point. In conclusion, farmers were taking care of each other to avoid their losses in the agricultural sector.

Moreover, there were $40.3 \%$ of the farmers who highlighted that fellow farmers want them to observe their results through ICTs. Still, $15 \%$ of the farmers were uncertain and $2.5 \%$ showed strongly disagreement on this point. It is quite natural that farmers also believe in seeing is believing. Therefore, by observing the results of fellow farmers they made their mind to take a risk or follow their procedures and ICTs could assist them to quickly share and apply in their own situations. Furthermore, social interactions also offer farmers to give a piece of advice to follow. In this regard, slightly half of the research population $(48.3 \%)$ agreed that they think the peer farmers should also able to assess agricultural risks individually so that they can easily minimize through appropriate agricultural risk management techniques. Yet, only $8.9 \%$ of the farmers displayed disagreement in this context.

There were more than half of the research population (55.6\%) who appeared agree that their fellow farmers should transfer new risk management techniques by the application of ICTs. Meanwhile, $10.6 \%$ of the 
farmers were uncertain and only 3.3\% of the farmers displayed disagreement on this statement. Thus, a good number of farmers held an opinion that new risk management techniques should be transferred to fellow farmers in order to manage the agricultural risks. Similarly, $61.1 \%$ of the farmers unveiled that the fellow farmers should try to use new ICTs for the effective management of agricultural risks. Although, $2.8 \%$ of the farmers appeared disagree on this point.

Additionally, $38.6 \%$ of the farmers stated that they expect to contact immediately for solutions of pest/ disease attack with fellow farmers to avoid any agricultural risk. However, $29.7 \%$ of the farmers were still unclear on this statement. Usually, farmers contact instantaneously whenever they notice any issue for timely curtailing of the disease or pest attack. Digital technologies assist farmers in this regard. Farmers may take a photo of the disease by zooming so it the issue should be clear for the viewer (s). Another way is to send a verbal (oral) message by describing signs and symptoms to the receiver who may be a fellow farmer or an extension agent to recommend an appropriate solution.

There were $38.3 \%$ of the farmers who revealed that their peer farmers want them to practice various risk management strategies for better farm production. Farmers are required to apply different risk management techniques because climate changes pose unalike risk with changed severity so after diversified practices, the good one could be selected and may be repeated. However, $24.2 \%$ of the farmers showed disagreement on this point. The deputed extension staff may help the farmer to adopt or adapt suitable risk management technique and share the good results with other farmers for the ultimate reduction of farm production.

Furthermore, farmers' containing 38.6\% displayed agreement that fellow farmers should also rely on expert recommendations for the management of agricultural risk through ICTs. Instead of taking a risk in decision making, farmers are needed to consult with agricultural extension or other expert (s) for apt risk mitigation help. Variety of digital tools and applications may assist farmers to make informed decision (s). Though, $18.1 \%$ of the farmers did not show strong agreement on this perspective. The reason could be less familiarity or credibility on the ICTs or on experts or lack of digital literacy to use ICTs in the agricultural sector.
There were $30.6 \%$ of the farmers who agreed that their fellow farmers want them to get the good results of implementing agricultural risk management strategies. Yet, $16.9 \%$ of the farmers demonstrated strongly disagreement in this regard. It can be gathered that appropriate and timely risk management techniques could reduce the risk and results may be replicated and become a lesson for other farmers. In addition, there were $19.7 \%$ of the farmers who reflected the agreement that their peers (fellow farmers) observed that they were weak to manage agricultural risk through new techniques and $39.4 \%$ of the farmers remained uncertain in this regard. It could be due to the reason that farmers are still less confident about their choice and decision (s) to manage agricultural risk appropriately and with the use of ICTs.

The overall mean (3.84) in Table 1 reveals that farmers had mixed opinions regarding the influence of subjective norms such as the pressure of fellow farmers, personal influence and influence of extension service providers. Although, the overall mean is close to four which means agreement on all 13 statements but still more efforts are required to strengthen social networks of farmers and bridge the gap between extension agents and farmers for tackling agricultural risk stem from climate changes.

Table 2: Level of subjective norms among respondents toward ICTs use for agricultural risk management $(n=360)$.

\begin{tabular}{lllll} 
Level & \multicolumn{2}{l}{ Frequency Percentage } & Mean S. D. \\
High (3.67-5.00) & 255 & 70.8 & 3.84 & 0.470 \\
Moderate (2.34-3.66) & 103 & 28.6 & & \\
Low (1.00-2.33) & 2 & 0.6 & & \\
Total & 360 & 100.0 & &
\end{tabular}

Source: Field survey.

\section{Level of subjective norms}

The result in Table 2 demonstrates the level of subjective norms among farmers as respondents about ICTs usage for agricultural risk management. Based on the results, $70.8 \%$ (255) farmers had a high level of influence of subjective norms, $28.6 \%$ (103) farmers had moderate level whereas, only $0.6 \%$ (6) farmers showed a low level of subjective norms influences. In conclusion, the level of the subjective norms was high as shown in the following table. The results are consistent with Yau and Ho (2015). The similar results were found by Bolong et al. (2016), 
who have examined the impacts of behavioural factors on wireless village services among Malaysian rural community.

\section{Conclusions and Recommendations}

In conclusion, the social influence cannot be under estimated and ignored in order to mitigate climate impacts as a risk in the agricultural sector is increasing. Therefore, present research was designed to examine the influence of subjective norms on ICT usage for agricultural risk management by farmers in Malaysia. The findings showed that farmers in social networks realized the importance of ICTs and encouraged each other to take advantage of digital interventions to minimize agricultural risks. The extension workers also influenced the farmers to stay in connects with them and also with fellow farmers through ICTs. The findings further revealed that overall, the level of subjective norms was high among the respondents which is a good sign of social bindings. Nevertheless, extension service providers are needed to put more efforts to socially organize the farmers for the ultimate reduction of agricultural risks and curtail the extreme climate changes.

\section{Author's Contribution}

The findings are from $\mathrm{PhD}$ research work of Muhammad Ali. Mr. Ali collected the data, wrote the manuscript and reviewed the literature. Norsida Man supervised the research, helped in data analysis and proofreading of the manuscript. Farrah Melissa Muharram also assisted in proofreading and editing of the manuscipt.

\section{References}

Adger, N., T.P. Hughes, C. Folke, S.R. Carpenter and J. Rockstorm. 2005. Socio-ecological resilience to coastal disasters, Sci. 309. 10361039. https://doi.org/10.1126/science.1112122

Ajzen, I. 1991. The theory of planned behavior. Org. Behav. Hum. Decis. Process. 50(2):179211. https://doi.org/10.1016/07495978(91)90020-T

Akhtar, S., G.C. LI, A. Nazir, A. Razzaq, R. Ullah, M. Faisal and M.H. Raza. 2019. Maize production under risk: The simultaneous adoption of off-farm income diversification and agricultural credit to manage risk. J. Integr.
Agric. 18(2): 460-470.https://doi.org/10.1016/ S2095-3119(18)61968-9

Aldosari, F., M.S. Al Shunaifi, M.A Ullah, M. Muddassir and M.A. Noor. 2017. Farmers' perceptions regarding the use of Information and Communication Technology (ICT) in Khyber Pakhtunkhwa, Northern Pakistan. J. Saudi Soc. Agric. Sci.

Ali, M., N. Man, I.A. Latif, F.M. Muharam and S.Z. Omar. 2018a. The use of information and communication technologies in agricultural risk management by the agricultural extension services in Malaysia. Int.J. Agric. Environ. Food Sci. (2)1: 29-35. https://doi.org/10.31015/ jaefs.18005

Ali, M., N. Man and F.M. Muharam. 2019. Perceptions of Malaysian farmers regarding their knowledge in agricultural risk management. J. Agric. Plant Sci. 29(4).

Ali, M., N. Man and F.M. Muharam. 2018b. An evaluation of risk adaptation practices by farmers in Malaysia. Региональные проблемы. 21(31): 136-139. https://doi.org/10.31433/1605220X-2018-21-3(1)-136-139

Alemayehu, A. and W. Bewket. 2017. Smallholder farmers' coping and adaptation strategies to climate change and variability in the central highlands of Ethiopia. Local Environ. 22(7): 825-839. https://doi.org/10.1080/13549839.2 017.1290058

Aniah, P., M.K. Kaunza-Nu-Dem and J.A. Ayembilla. 2019. Smallholder farmers' livelihood adaptation to climate variability and ecological changes in the savanna agro ecological zone of Ghana. Heliyon. 5(4). https://doi.org/10.1016/j.heliyon.2019.e01492

Bernier, Q. and Meizen-Dick. 2014. Resilience and social capital, Building resilience for food and nutritional security. IFPRI 2020 Conference. Addis Ababa, Ethopia, May 17-19. Washigton, D. C. Int. Food Policy Res. Inst. (IFPRI).

Bolong, J., H.A.M. Shaffril, S.Z. Omar, J.L. D’Silva and H. Sahharon. 2016. Examining the impacts of behavioral factors on wireless village services among rural community in Malaysia. Int. J. Acad. Res. Bus. Soc. Sci. 6(6): 338-354. https:// doi.org/10.6007/IJARBSS/v6-i6/2201

Cadger, F., K. Curran, J. Santos and S. Moffett. 2016. Location and mobility-aware routing for multimedia streaming in disaster telemedicine. Ad Hoc Networks. 36: 332-348. https://doi. 
org/10.1016/j.adhoc.2015.08.016

Di Falco, S. and S. Sharma-Khushal. 2019. Cognitive drivers, and the effect of information on climate change adaptive behaviour in Fiji Islands. Environ. Sci. Policy. 92: 245-254. https://doi.org/10.1016/j.envsci.2018.11.019

El Bilali, H. and M.S. Allahyari. 2018. Transition towards sustainability in agriculture and food systems: Role of information and communication technologies. Inf. Process. Agric. 5(4): 456-464. https://doi.org/10.1016/j. inpa.2018.06.006

Haftu, G.G. 2019. Information communications technology and economic growth in SubSaharan Africa: A panel data approach. Telecommun. Policy. 43(1): 88-99. https://doi. org/10.1016/j.telpol.2018.03.010

Isaac,M.E.2012.Agricultural information exchange and organizational ties: The effect of network topology on managing agrodiversity. Agric. Syst. 109: 9-15. https://doi.org/10.1016/j. agsy.2012.01.011

Jellason, N.P., R. Baines, J. Conway and C.C. Ogbaga. 2019. Climate Change Perceptions and Attitudes to Smallholder Adaptation in Northwestern Nigerian Drylands. Soc. Sci. (8)2. https://doi.org/10.3390/socsci8020031

Lehmann, R.J., R. Reiche and G. Schiefer. 2012. Future internet and the agri-food sector: Stateof-the-art in literature and research. Comput. Electron. Agric. 89: 158-174. https://doi. org/10.1016/j.compag.2012.09.005

Matuschke, I. 2008. Evaluating the impact of social networks in rural innovation systems: An overview; Int. Food Policy Res. Inst. Washington, DC, USA, Vol. 816.
Mubiru, D.N., M. Radeny, F.B. Kyazze, A. Zziwa, J. Lwasa, J. Kinyangi and C. Mungai. 2018. Climate trends, risks and coping strategies in smallholder farming systems in Uganda. Clim. Risk Manage. 22: 4-21. https://doi. org/10.1016/j.crm.2018.08.004

Naylor, R. and P. Courtney. 2014. Exploring the social context of risk perception and behaviour: Farmers' response to bovine tuberculosis. Geoforum. 57: 48-56. https://doi. org/10.1016/j.geoforum.2014.08.011

Olorunfemi, T.O., O.D. Olorunfemi and O.I. Oladele.2019. Determinants of the involvement of extension agents in disseminating climate smart agricultural initiatives: Implication for scaling up. J. Saudi Soc. Agric. Sci. https://doi. org/10.1016/j.jssas.2019.03.003

Selwyn, N. 2002. Defining the 'digital divide': developing a theoretical understanding of inequalities in the information age (Occasional Paper 49). Cardiff: Cardiff Univ.

Shikuku, K.M. 2019. Information exchange links, knowledge exposure, and adoption of agricultural technologies in northern Uganda. World Dev. 115: 94-106. https://doi. org/10.1016/j.worlddev.2018.11.012

Wang, X. 2018. The role of attitudinal motivations and collective efficacy on Chinese consumers' intentions to engage in personal behaviors to mitigate climate change. J. Soc. Psychol. 158(1): 51-63. https://doi.org/10.1080/00224545.201 7.1302401

Yau, H.K. and T.C. Ho. 2015. The influence of subjective norm on behavioral intention in using e-learning: An empirical study in Hong Kong higher education. Proce. Int. Multi Conf. Eng. Comput. Sci. 